\title{
'Passivity' or 'Potential'? Teacher responses to learner identity in the low-level adult ESL literacy classroom
}

\author{
SUE OLLERHEAD
}

\begin{abstract}
This paper explores some initial findings from a multi-site, classroombased case study research project into English as a Second Language (ESL) literacy provision to very low-literate adult learners within Australia's Language, Literacy and Numeracy Program (LLNP). The aim of the research is to report on the researcher's observations of teachers' pedagogical practices and to investigate the extent to which they are responsive to learners' developing and multiple identities.
\end{abstract}

\section{Introduction}

This report discusses data gathered through in-depth interviews with LLNP head teachers and classroom teachers, which revealed their use of deficit labelling in relation to low-literate learners within their program. Four of the six teachers interviewed referred to their learners as 'passive' and 'lacking' in terms of their linguistic ability.

The investigation is situated within a research tradition that views the identities of learners as being multiple, varying and contingent on the way learners are positioned in society, acting as a form of 'potential'. Researchers such as Norton $(2000,2001,2010)$ and Toohey $(2000)$ advocate the need for teachers to engage in pedagogical practices that enhance, rather than limit the identity positions available to learners, thereby allowing them the best prospects for language learning and participating meaningfully in a range of social contexts.

As well as drawing on teacher interviews, the study reports on observations of classroom teaching with the aim of investigating which pedagogical practices appeared to offer learners a broader variety of identity positions from which they could speak, read, write or listen in English. It also seeks to explore those teaching practices that appeared to limit or constrain learners' identity positions, effectively silencing them and constraining their classroom participation.

\section{Literature review}

Contemporary educational research into the compelling relationship between identity and language learning has gathered increasing momentum over the past two decades (Goldstein 2003, Harklau 2000, Hornberger \& 
Skilton-Sylvester 2000, Hornberger, 2003, Norton, 1997, 2000, 2001, 2010, Norton Pierce 1995, Norton and Toohey 2004, Toohey 2000). Within such scholarship, identity is conceptualised as multiple, varying and a site of struggle, in terms of who has better access to the target language in a society constituted by unequal relations of power (Norton and Toohey 2011). In language teaching contexts, this research highlights the dynamic ways in which teachers allocate certain identity positions to learners through their pedagogical practices. It also explores how learners either accept or resist these positions, and in some cases, lay claim to more powerful identities.

While identity work in language education is gaining currency within an Australian research tradition and within the field of adult literacy research in particular (Wallace 2008, Miller 2011), little empirical research has been conducted with very low-literate learners in Australia. Given the growing numbers of these learners in Australian English language and literacy classes (McKenna and Fitzpatrick 2005, Wigglesworth 2003) and the linguistic and cultural challenges they present to teachers, there appears to be a pressing need to identify and document current and effective practices. This study aims to shed light on situated Australian classroom practices with very low-literate adult literacy learners within the specific context of the Language, Literacy and Numeracy Program (LLNP), a government-funded course with the broad aim of 'equipping learners for the workplace' (see Department of Education, Employment and Workplace Relations site http://llnp.deewr.gov.au ).

According to Norton and Toohey (2011) identity research, with its related theoretical constructs of 'investment', referring to learners' desire and commitment to learn a language vis-à-vis prevailing classroom language practices, and 'imagined identities', denoting learners' aspirations to occupy more socially powerful identities, is a useful vehicle through which to analyse language learning. This is because learners' hopes for the future are integral to their language learner identity.

For many learners, the target language community is not only a reconstruction of past communities and historically constituted relationships, but also a community of the imagination, a desired community that offers possibilities for an enhanced range of identity options in the future. (Norton and Toohey 2011: 415)

While 'hopes for the future' are relevant to the personal aims of all learners embarking on the complex task of learning a new language, they are particularly salient in the case of very low-literate adult learners in Australia, who are frequently newly arrived migrants, many of whom have 
refugee backgrounds. They are thus actively engaged in navigating new and unfamiliar social, cultural and economic networks, where 'language learner' is but one of several new identities assigned to them.

\section{Theoretical framework}

The shift away from predominantly structuralist studies into linguistic competence, where language was viewed as a system of idealised, syntactic rules, can be traced back to Russian philosopher Mikhail Bakhtin (1986), who proffered a post-structuralist perspective on language.

Bakhtin viewed language as a dynamic, dialogic process of communication, where speakers respond to what has been said before and in anticipation of a response to come. His work focused on the social positioning of speakers and how this affected their right to speak. In a similar vein, sociologist Pierre Bourdieu (1977) investigated the political impact of language, in particular how the right to speak was closely linked to the ability to access power in society. Furthermore, he acknowledged that access to societal power was variable and context-dependent. Language could therefore be viewed in economic terms as a symbolic commodity, whose value fluctuated according to the 'market' or context in which it was offered.

Feminist post-structuralist Christine Weedon (1997) highlights the link between identity and language learning through her assertion that language is the medium through which individuals negotiate a sense of self identity. She also describes language as the vehicle through which individuals are granted or denied access to social networks that allow them to be heard.

Weedon advances the notion of 'subjectivity' to account for the relational aspect of identity. In her view, one is either the subject of a set of relationships, in a position of power, or subject to a set of relationships, in a position of diminished power. Weedon therefore sees the way in which individuals identify themselves as being inextricably linked to their social relationships, which are constructed through the medium of language. Far from being static, these relationships are fluctuating, dynamic, developing over time, building both through discourse practices and heavily influenced by social and historical factors.

Such a conceptualisation of identity conflicts with research into psychological traits such as motivation, explored in Dornyei's earlier work (1994), where the learner is perceived as having a unitary, fixed, ahistorical personality. Norton (2010) believes that this kind of framework leads researchers and teachers to label learners with fixed and often binary characteristics, such as 'motivated or unmotivated', 'passive or engaged'. A sociological view of language contradicts this by saying that learners have multiple identities that come to the fore as a result of the social relationships around them. 


\section{The construct of 'investment'}

Norton's ethnographic study of immigrant women in Canada (2000) found that motivation by itself was not necessarily a precursor to successful language learning. Instead, it revealed the pivotal role that inequitable power relations played in determining her participants' ability to access the second language. This led to Norton's conceptualisation of the term 'investment' (Norton Pierce 1995, Norton 2000, 2010). Investment is a construct that views learners as having complex and changing identities, which manifest differently in varied social situations. It connects a learner's aspiration and dedication to learning a language, to their changing identity. As Norton and Toohey (2004) argue, even if learners are highly motivated, they may nevertheless have little investment in the language practices of a classroom that are, for example, racist or culturally inaccessible. Erstwhile motivated learners could feel excluded from the language practices of such a classroom, and over time may come to be positioned by teachers as 'disinterested' or 'unmotivated'.

Norton (2010) therefore stresses that it is important for teachers to reflect on the extent to which learners are invested in the target language practices of their low-level adult literacy classroom. More importantly, teachers should consider how they respond or adapt to those learners who appear to not to be invested in the literacy practices of their own particular classroom.

Reeves' (2009) examination of an English teacher who negotiated his teacher identity in relation to English language learners (ELLs), offers useful insights into the way teachers position learners. She argues that teachers bring their own attitudes, convictions and discourses to bear when attributing identity positions to learners. These may include their understanding of how learners acquire a second language, their attitudes towards low-literate learners or the extent to which they are influenced by the institutional discourse surrounding low-literate learners. Furthermore, such factors do not always act in learners' favour:

To the extent that teachers hold misconceptions regarding second language learning, assimilative impulses towards ELLs (English language learners), or biases against immigrant students or particular immigrant groups, the likelihood of teachers positioning ELLs in unhelpful or even damaging ways increases. (Reeves 2009:39)

Moreover, Reeves' study also suggests that teachers may invest in specific identity positions for language learners as a way of establishing their own identities, implying teachers' 'self-interest' in defining their learners (2009:37). For example, teachers who feel overwhelmed by the linguistic challenges posed by low-literate learners, may position their learners as 
'lacking in ability' to deflect their responsibility for learners making little or slow progress in acquiring the target language.

\section{Human agency}

One of the central tenets of identity research in language teaching is that of human agency. Norton and Toohey (2011) note that although language learners may be deeply affected by structural conditions, such as a lack of resources, their social relationships or historical backgrounds, they also have the ability to calibrate or realign their relationships with fellow speakers. In so doing, they can assume different and possibly even more powerful identities from which to interact in the target language. This in turn enhances their potential to acquire the target language. It follows, therefore, that the extent to which teachers engage in pedagogical practices that encourage learners to exercise this agency, can be a determining factor in learners' ultimate acquisition of the target language.

Human agency is also highly relevant to language teachers, in the sense that they have the ability to resist highly limiting policy environments, or situations where resources are limited or forcefully prescribed.

Hornberger (2003) views the power relations present in literacy teaching environments as being flexible and 'open to transformation' through what teachers do in their classroom practices. Pippa Stein's (2008) examination of transformative teaching practices in South African township schools illustrates the ways in which both teacher and learner agency can work together to enhance identity positions and language learning opportunities for learners. Stein describes the innovative ways in which teachers rediscovered culturally relevant texts and objects which had previously been suppressed under apartheid. They also used multiple modes of learning, such as linguistic, physical and sensory methods, to engage learners' diverse and developing identities.

Human agency is also a factor in considering ways in which learners express resistance to being positioned in undesirable ways. These can include covert literacy activities in the classroom, such as discussing classroom matters in the mother tongue, to compensate for social losses (Canagarajah 2004), or subversive learner behaviours such as failing to complete homework or neglecting to bring materials to class (Talmy 2008). Chief amongst these, however, is the use of silence in the classroom. Duff (2002) reports on a classroom study in a multilingual Canadian classroom, where English language learners avoided speaking in an attempt to protect themselves from the 'humiliation' of having their poor command of English compared with their native learner counterparts. In such a case, notes Duff, learners' silence was not necessarily reflective of their lack of initiative or interest, but rather an act of agency to communicate that they were more invested in the written practices of the classroom than the spoken ones. 
Passivity' or 'Potential'?

Similarly, White (2011:250) reports on the need for teachers to be aware of personal and cultural issues in multilingual classrooms when initiating classroom discussions as a teaching tool. He cautions that cultural and linguistic differences in learner groups can mean that not all learners are familiar or comfortable with the conventions of classroom participation.

Norton (2010) asserts that human agency can have a transformational impact when applied to language teaching practices that acknowledge the multiple and changing identities of learners, highlighting the learning and social benefits of such an approach. She argues the need for teachers to be critically self-reflective, in examining how relations of power in the classroom promote or limit the conditions under which learners speak, and also the extent to which learners are valued when they speak or remain silent in the classroom.

When teachers offer narrow identity opportunities to learners, they often represent them in deficit terms of how they are 'lacking' in certain knowledge or skills, or according to what they cannot do.

\section{Deficit models of literacy}

Research carried out by Tett, Hamilton and Hillier (2006) into the impact of the use of deficit discourse or labelling practices by teachers, reports that many learners who were labelled as 'deficient" in terms of formal school literacies, struggled to shake this epithet in later years. This in turn led them to develop negative perceptions of themselves as learners in most learning situations.

Similarly, Black and Yasukawa (2011) claim that deficit labelling practices can have negative consequences for both teachers and learners alike. They suggest that the deficit approach can lower teachers' expectation of individual learners' literacy potential, and can also lead them to limit their efforts at providing meaningful learning support. Another possible consequence of a deficit approach is what Villenas (2001:4) terms 'benevolent racism', where learners are generally perceived as having a language 'problem', and are attending literacy class to 'fit better into society and to learn the Australian way of life'. Such an attitude places very little store on the life experience and cultural capital that adult learners bring to a classroom learning situation.

Black and Yasukawa (2011) support Tett and others' (2007) finding that deficit labelling can negatively affect learners' concept of themselves. As Taylor argues (1992:25), recognition, or the absence thereof, frequently manifested in misrecognition by others, can play a large role in shaping our identities. It is Taylor's view that individuals or social groups can suffer real damage or distortion, if the society in which they are placed reflects a debasing or derisive image of themselves back to them. 
This would seem to suggest that ascribing deficit labels to learners can have a very real effect on teachers' pedagogical practices, and the ways in which they are received by learners.

Deficit discourses are most frequently located within learning environments that ascribe to an 'autonomous' view of literacy (Street 1984, 2001). In such settings, literacy is viewed as a body of discrete, cognitive skills that are independent of the context in which they are used and can be assessed in a uniform, systematic way. Hamilton, Hillier and Tett (2006) liken the route by which these skills are obtained to a ladder that has to be climbed, where people are ranked from top to bottom with the emphasis on the skills they cannot perform rather than those that they are able to demonstrate. This leads to a deficit model where those on the bottom rungs are positioned as being deficient in the skills that those with more authority or societal power think they need.

The Australian Language Literacy and Numeracy Program (LLNP) claims to provide 'high quality, flexible training' to its clients, to meet a growing need for vocationally oriented literacy and numeracy training (http://www.llnp.deewr.gov.au). Its clients, who are mostly referred by the government's social security agency Centrelink, attend training for a maximum of 19 hours a week, in blocks of up to 160 hours, after which they are assessed using the National Reporting System (NRS)1. Learners are expected to make two NRS 'improvements' in two separate learning outcomes in each 160-hour block of tuition. It could be argued that such an approach to language assessment, in which learners have to achieve narrowly prescribed outcomes within decidedly regulated time periods, appears to lean towards an autonomous literacy framework.

This review of the literature serves as a framework within which to analyse the selected research data. It also generates the core key research questions to be addressed in this study, namely :

- How did teachers conceptualise the identities of their learners?

- Which of the teachers' observed pedagogical practices appeared to enhance the variety of identity positions available to learners, enabling their classroom participation?

- Which pedagogical practices appeared to limit the identity positions available to learners, thereby constraining their classroom participation?

\section{Methodology}

The interview data and classroom practices analysed in this paper were taken from a larger multi-site case study research project, which involved two head teachers, four teachers and 53 learners in four different classrooms located at two large vocational training colleges. 
The teachers and learners knew the researcher as a South AfricanAustralian English speaking former literacy and ESL teacher, who was conducting the research as part of a doctoral thesis. Over a period of three months, the researcher observed each classroom on six different occasions for two hours, providing a total of approximately 48 hours of classroom observation data. To complement this data, the researcher interviewed head teachers and classroom teachers and conducted learner focus group interviews, with the assistance of interpreters from the core language groups.

\section{Challenges}

The key challenges faced by researchers using qualitative methods are well documented. Schachter and Gass (1996:ix) advocate having a flexible agenda when undertaking classroom-based research, because the initial goals of the project often need to be modified according to 'exigencies of time, place and individuals'. Leung, Harris and Rampton (2004) report on the difficulty qualitative researchers experience in presenting the sheer volume of often ambiguous data that does not conform to neat categories. Duff and Early (1996) group the difficulties posed by classroom-based language teaching research into institutional, ethical and methodological challenges. The researchers' experiences of each of these challenges during the course of this study are briefly outlined below:

\section{Issues of access}

Duff and Early emphasise how classroom-based education research often involves multiple stakeholders with conflicting agendas, which can make access to research sites difficult. The researcher had initially planned to conduct her field research within a major national migrant English language program. On application, she was advised that gaining access to low-literate learners within this program would be nigh impossible, as research with this learner population was the domain of a government funded research body based at a large Australian university. The researcher canvassed support from nine private and public providers of literacy tuition to very low-literate learners. It took five months to gain a positive response, after several rejections citing teachers' heavy workloads which reduced their capacity to participate in voluntary research activities.

As well as institutional access, however, the researcher needed to obtain 'buy-in' from the classroom teachers. Teachers were, after all, under no obligation to participate in the research and their co-operation in the project would place demands on their personal time with no material compensation. Shachter and Gass (1996) point to the necessity of establishing relationships and feelings of trust with the teachers whose classes are being observed. It took several weeks of phone and email communication and two informal visits with the teachers before they 
reached the view that co-operation in the project could be beneficial if it highlighted the unique challenges that they faced in teaching very lowliterate learners.

Finally, the researcher needed to obtain the trust of the learner participants themselves. In this sense, the choice of a case study research design worked in the researcher's favour. The fact that the classroom observations sessions were conducted over a period of three months, allowed the researcher an opportunity to gradually build a relationship of familiarity and rapport with the learners. This included accompanying two of the classes on a numeracy excursion to a fresh produce market, affording the researcher an opportunity to bond with the learners and gauge their oracy, literacy and numeracy levels on an informal level.

\section{Ethical considerations}

Yet another crucial consideration for classroom-based researchers is that of maintaining ethical research practices. In this regard, the researcher underwent a thorough university ethics approval process, with comprehensive guidelines regarding participants from refugee backgrounds. Duff and Early (1996) point out, however, that while institutional prescriptions are helpful, they are not always unequivocal, and that researchers are often required to make 'on the spot' ethical judgments. Such a situation arose during the course of the study when learners began to divulge unsolicited personal details about their historical backgrounds during focus group interviews. In such instances, rather than prescribing to learners what they were allowed to discuss in the interview, the researcher responded to the information informally. She chose not to document the unsolicited data in her research report.

An outline of the research design and data analysis approach employed by the researcher are outlined below.

Research design and methods

The larger investigation within which this research report is situated, took the form of a multi-site case study, comprising four classrooms located in two different vocational institutions. The study adopts Cresswell's (1998:36) definition of a case study as 'the exploration of a bounded system (or systems) over time through detailed, in-depth data collection involving multiple sources of information rich in context'.

Data collection procedures included audio-recording of both classroom lessons and interviews with participant head teachers and teachers, as well as learner focus groups. Interpreters from learners' core first language groups were recruited to assist with concurrent translation. Each two hour lesson was observed and scripted retrospectively from the audio recordings. Field notes were kept to record informal conversations and salient observations made during each lesson. In addition, texts and 
documents related to the program were collected. These included course program outlines, curriculum documents and media articles. This study is located within a sociocultural framework of identity that views language as being inextricably linked to identity. For this reason, interviews, focus group sessions, informal conversations and classroom interactions were analysed in terms of both learners' and teachers' construction of identity. Field notes and documents were used as artefacts to support the analysis, and also as a means of triangulating the data to strengthen the findings. (Duff 2008, Nunan,1992, Stake 1995).

Research participants

The participants reported on in this study included two head teachers of the program, two classroom teachers and 21 learners. The head teachers Rose and Marian² had overall responsibility for the management of the program, curriculum planning and teacher recruitment. In contrast, the two classroom teachers, Paula and Lucy, were responsible for the 'on the ground' delivery of literacy tuition to low-literate learners, as well as assessing and reporting on learners' progress.

The learners were described by their teachers as having mostly refugee backgrounds, coming from strife-torn regions of Africa and Asia, where their schooling was severely disrupted as a result of violent conflict and displacement. Most learners had limited or no literacy skills in their first languages (L1s) and also very little experience of formal learning situations. Generally, learners attended class for five hours a day, three days a week.

\section{Findings and discussion}

\section{Teacher conceptualisations of learners' identities}

In an initial interview with head teacher Rose, she related the key administrative and policy challenges confronting her classroom teachers within the LLNP, including the high administrative load imposed by the reporting mechanism and the unique and complex needs of very low-literate learners.

Rose felt that the adult literacy teaching sector as a whole was largely ill-equipped to tackle the multiple, intense and complex challenges of teaching learners with distinctly low levels of literacy and highly specific and complex social and settlement needs. She stated:

We were caught, the Sudanese crept up on us. Maybe four years ago, none of us had taught that kind of learner. Then suddenly, the Sudanese were upon us, and the Afghan women were upon us, and so were kind of, we were existing teachers, but even if you had expertise at teaching lower levels, they were 
educated, they had literacy, so it's completely different.

(Interview extract)

Head teacher Marian spoke to the difficulties teachers experienced in responding to the specific linguistic and social needs of distinctly multicultural beginner classes:

It's very hard to know what they (the learners) want to achieve, because they haven't got enough language, and we don't speak Dinka, or Urdu, or Farsi. (Interview extract)

The phrases 'that kind of learner' and 'they haven't got enough language' are representative of the deficit discourse used by both head teachers when referring to low-literate learners in their recorded interviews. Such data suggests that both head teachers conceptualised the identities of Level 1 language learners in fairly fixed and unitary terms. There was little evidenced recognition of the potential for inequitable power relations to exist between highly literate L1 teachers and very low-literate L2 learners. In this way, the data suggests that the head teachers conceptualised identity in terms of reflecting the 'essence' of their learners, rather than a process of 'becoming' which would allow scope for development and change (Hall 1997).

Level 1 classroom teachers Lucy and Paula demonstrated slightly different conceptualisations of learner identity in their interview responses. Lucy described her teaching as very demanding and at times, 'depressing'. She felt that her efforts to engage her learners using varied approaches and techniques were meeting with little success. This left her feeling 'mentally exhausted'.

In contrast, Paula related how she relished the challenge of teaching beginner learners, viewing it as an opportunity to find out more about 'how learners learn'. She readily acknowledged that her teaching was a dual process of analysing and presenting language according to specific learner needs, and admitted that she 'didn't always get it right'. Instead, her teaching was a process of constant learning and self-questioning. It could be argued, therefore, that Paula's conceptualisation of her own identity as an evolving and developing language teacher facilitated her view of learners as being in the process of 'becoming'. She thus interpreted her role as offering learners as many identity positions as possible from which they could interact in the classroom.

One possible reason for the differing ways in which Lucy and Paula appeared to conceptualise learner identity could lie in Jennings' (1996) 
assertion that teachers' experiences, ideas and beliefs can determine how they work within educational policy contexts and how they exercise agency in translating policy into instructional practices.

An earlier study by Ollerhead (2010) related Paula's initial teaching experience with learners who had been refugee victims of torture and trauma. Her strong commitment to the humanistic and social concerns of her learners led her to recognise their potential in the form of offering them various identity positions through various modes of learning.

In contrast, Lucy came from a far more authoritarian teaching background, where policy was strictly adhered to and observed, allowing less room for innovation and adaptation. Ollerhead (2010) concluded that Paula and Lucy's backgrounds played a role in their ability to exercise their human agency to utilise transformative pedagogy in the classroom.

The way in which both Paula and Lucy positioned their learners will now be discussed in terms of their pedagogical practices, as illustrated by observation data gathered during two-hour lessons in each classroom.

\section{Observed pedagogical practices}

\section{Paula's lesson}

Paula's class comprised 13 learners, representing six nationalities. Of the 13 learners, 12 were female and one was male. The learners' median age was 39 , and they had a median number of formal schooling years of two. Seven of the learners reported having two first languages (i.e. they were equally proficient in both languages.) See Table 1.

Paula's lesson focused on vocabulary, reading and writing tasks about health-related issues.

In the first stage of the lesson, Paula played learners a simple recorded dialogue of a doctor-patient interaction. She then asked learners to match selected phrases from the dialogue to form complete sentences. The learners read the sentences in pairs, then together as a class. Paula called out the beginning of sentences and asked learners to complete them aloud without looking at their worksheets. She then invited learners to recite the dialogue as a class, inviting them to beat the rhythm with their hands on their desks. Eventually, learners were able to recite the entire dialogue without referring to the script. The teacher elicited contributions from all class members, paying careful attention to their pronunciation and intonation. Throughout this stage, Paula insisted that learners 'listen, remember and speak', rather than write.

In the second stage of the lesson, Paula changed the classroom dynamic by inviting learners to arrange their chairs in a large circle at the front of the room. She initiated a classroom discussion by miming that she had a headache. She elicited the question 'What do you do when you get a 
'Passivity' or 'Potential'?

headache?', to which the learners responded with various remedies, such as 'I take Panadol', or 'I drink water'. The teacher then invited learners to repeat the target question aloud and then individually, again paying careful attention to pronunciation and intonation. She substituted the term 'have a headache' with alternatives such as 'have a stomach ache' or 'flu', and elicited various remedies, such as drinking 'flat' coca-cola. These remedies were repeated and practised and key phrases such as 'take Panadol' were written up on the whiteboard.

\begin{tabular}{|l|l|l|l|l|}
\hline Nationality & First languages & Age & Gender & $\begin{array}{l}\text { Years of } \\
\text { schooling }\end{array}$ \\
\hline Vietnamese & Vietnamese & 42 & F & 4 \\
\hline Sri Lanka & Tamil/Sinhalese & 49 & F & 0 \\
\hline Sudanese & Denka/Arabic & 52 & F & 0 \\
\hline Sudanese & Denka/Arabic & 46 & F & 0 \\
\hline Sudanese & Nuba/Arabic & 34 & F & 0 \\
\hline Sudanese & Denka/Arabic & 34 & F & 4 \\
\hline Sudanese & Arabic & 28 & F & 7 \\
\hline Sudanese & Nuer/Arabic & 29 & F & 4 \\
\hline Sudanese & For/Arabic & 36 & M & 0 \\
\hline Afghani & Farsi & 48 & F & 0 \\
\hline Afghani & Dari & 44 & F & 3 \\
\hline Pakistani & Urdu & 42 & F & 0 \\
\hline Korean & Korean & 34 & F & 8 \\
\hline
\end{tabular}

Table 1: Learner participant backgrounds in Paula's classroom

Learners seemed highly engaged and stimulated by this topic, frequently alternating between their first language, English and mime actions to offer various remedies to different ailments. At no stage did the teacher insist that learners spoke in English, and provided vocabulary input only where and when it was requested. Learners also became distinctly animated during this stage of the lesson, enthusiastically miming traditional remedies such as picking herbs from plants and inhaling them over the smoke of a fire. This stage was also accompanied by a high level of humour, with learners expressing mock horror at culturally unfamiliar remedies, such as acupuncture in the case of the Sudanese learners.

\section{Discussion}

In this lesson, Paula successfully elicited learners' multiple identities as parents, nurturers, healers and consumers by contextualising the content using subject matter that they found interesting, relevant and engaging. Learners were afforded the opportunity to integrate both vernacular and multi-modal forms of presentation into their language use, such as chanting and mime. According to Norton (2010), the use of multimodal pedagogy 
can help learners to develop ownership of the target language when it is used for authentic communication and expression, rather than viewing it as a skill which has to be learned 'correctly'. Paula's success in appealing to her learners' multiple and diverse identities allowed them to express their unique and situated knowledge as parents, nurturers, healers, consumers and as survivors of intense hardship. For example, a Sudanese class member, with the help of an interpreter, shared with the rest of the class that she had grown up in a nomadic family of pastoralists, who moved constantly through the deserts in search of food for crops. As a result, she had developed unique navigation and environmental skills, such as where to find water, how to handle animals, and the hard work of survival during times of drought. Here the teacher used her knowledge of the particular historical and social context of her learners to draw on their unique knowledge basis, which in turn made them feel valued.

Overall, Paula's lesson was characterised by an energetic, lively atmosphere. Interaction amongst learners was generally very high, with the teacher often playing a peripheral, facilitative role, while learners proceeded with communicative tasks such as group surveys and small group discussions. The benefits of such an approach were evident in learners' obvious enjoyment of the lesson. This was voiced by learner Nancy, a young mother with little formal education but who had made significant improvement while attending the class:

I love here at [college] the way the teacher teaches. She lets us laugh and enjoy to learn English. To know more, to try, I'm happy with that. (Interview extract)

\section{Lucy's lesson}

Lucy's class comprised 8 female learners, representing five nationalities. Their median age was 53, and their median number of formal schooling years was 4 . Five of the learners reported speaking two first languages.

Lucy's lesson focused on vocabulary and writing tasks associated with leisure activities. She began the lesson by attempting to elicit a classroom discussion, using key vocabulary associated with visiting the beach and other popular Australian customs, such as fishing and holding barbeques. Lucy addressed several direct questions to her learners, which met with little or no response. This stage of the lesson was marked by decidedly low levels of learner participation and engagement, as can be witnessed in the following transcript segment recorded during the classroom observation: 
'Passivity' or 'Potential'?

1 Lucy: Today we're going to be talking about 'Going to the beach' because that's what Australians like to do.

2 Lucy: How many of you have been to the beach? (9.8)

3 Lucy: How many of you have been to the beach, huh? (7.9)

4 Learner 1: I go with school (.) but windy, rainy.

(Extract from classroom transcript)

\begin{tabular}{|l|l|l|l|l|}
\hline Nationality & First languages & Age & Gender & $\begin{array}{l}\text { Years of } \\
\text { schooling }\end{array}$ \\
\hline Chinese & Mandarin & 47 & F & 8 \\
\hline Kurdish & Kurdish & 49 & F & 6 \\
\hline Samoan & Samoan & 54 & F & 8 \\
\hline Sudanese & Madi/Arabic & 64 & F & 0 \\
\hline Sudanese & Nuba/Arabic & 46 & F & 6 \\
\hline Sudanese & Denka/Arabic & 54 & F & 0 \\
\hline Sudanese & Denka/Arabic & 64 & F & 4 \\
\hline Liberian & Madingu/Arabic & 47 & F & 0 \\
\hline
\end{tabular}

Table 2: Learner participant backgrounds in Lucy's classroom

In the second stage of the lesson, learners were given a worksheet, with pictures depicting different beach scenes. Learners were asked to fill in the correct vocabulary in the spaces provided next to each picture, by choosing from a list of words written up on the board. There was silence in the classroom as learners attempted the activity, many of them taking a long time to correctly form the letters of each word. Lucy focused on the form of the words 'spade', and 'swim', by inviting learners to repeat the different blends 'sp' and 'sw'. She drew attention to the lengths of different words starting with the same first letter, such as 'swim' and 'sandcastle'.

\section{Discussion}

It was evident that Lucy had spent a large amount of time and effort in producing teaching materials that presented language in a methodical and structured way. She focused on the form of language by breaking words down into their composite phonemes and syllables and presented them on different coloured bits of paper. She also invested a lot of effort in producing worksheets around lesson topics. However, the materials presented in this lesson were largely de-contextualised, presenting learners with distinctly westernised concepts such as going to a barbeque, the importance of applying sunscreen or the different types of swimwear that one can wear at 
the beach, which were culturally inaccessible to learners, many of whom were devout Muslims who wore the hijab.

Throughout lesson 2, Lucy provided most of the input in the form of protracted, rhetorical 'teacher talk' (see Ritchie and Bhatia 1996, Gass 1997, Lightbown and Spada 2006), which met with little engagement or response from learners. The identity positions on offer to learners during this lesson were arguably narrow, consisting mainly of that of 'the other'. Learners were situated firmly outside the discourse through the teacher's use of the third person 'they', as in 'they (Australians) have a barbeque'. The teacher also offered a fairly one-dimensional cultural perspective of 'what it means' to be an Australian or 'Ozzie' in an urban context. The lack of response from learners underscores the vast distance between the teacher's discourse and that of the learners' historical and social backgrounds.

Interviews conducted with Lucy revealed her frustration and despondency at the long periods of silence that met her intense, varied efforts to engage learners with English. According to Duff (2002: 312) silence may be an indicator of active resistance on the part of learners. She posits that while silence may be a practical response of language learners to protect themselves from being scrutinised or humiliated for demonstrating their lack of literacy skills, it can also be a clear indicator that learners are not 'invested' in the practices of the classroom. In the context of this lesson, learners' unenthusiastic response to the topic of visiting the beach, were verbalised in Learner 1's response that she had in fact been to the beach before, 'but it had been windy and rainy', implying that it had not been a pleasant experience.

\section{A missed opportunity}

Significantly, field notes recorded while observing informal learner interaction before the lesson commenced identified, in the researcher's opinion, a missed opportunity for the teacher to capitalise and build on her learner's rich and diverse literacy practices.

Minutes before the formal lesson began, a learner from Liberia told the teacher that she would not be attending class the next day, as she would be going to the airport to farewell a relative who was attending the Hajj in Mecca. This comment generated a lot of interest from the other class members, both those who were Muslim and understood the significance of the event, as well as those who wanted to know more about the Hajj and where Mecca was located. At this point, two learners quickly located Saudi Arabia on a classroom map of the world to point out the location to the rest of the group. This interaction met with little response from the teacher, who 
allowed learners to talk amongst themselves and then called for their attention once she had finished setting up for her lesson.

(Field note extract)

There are many plausible reasons for Lucy's decision not to act upon learners' existing literacy practices in this situation. Chief amongst these are the pressure that she related being under to teach learners the necessary skills they needed in order to 'progress' according to the LLNP reporting standards. Lucy's professionally crafted classroom materials also indicated that her lesson was carefully planned and staged, and she was possibly eager to get maximum use from them, knowing that her learners worked at a slow pace.

Nevertheless, for the researcher, this 'literacy event' (Street 2001), featuring the Hajj, provided the teacher with concrete evidence of what learners were already able to do with regard to their existing literacy practices, and how they were able to draw on each other to mediate concepts that were unclear to them. It could be argued that this learner interaction could have acted as a springboard for a deeply contextualised lesson on the significance of religious ceremonies or special events in learners lives in which they had demonstrated an active interest.

Conclusion

To summarise, the aim of this research is to explore ways in which this particular case study is relevant to existing contemporary theory on language and identity. It also seeks to add to existing debates, discussions and issues in this field of adult literacy pedagogy and language and identity research.

This preliminary discussion of the research findings aims to illustrate that, perhaps unwittingly, teachers of low-literate adults can often engage in pedagogical practices that support a deficit model of literacy, which not only offer learners' inferior identities as learners, but also prevent them from engaging in meaningful learning opportunities and more engaged and fulfilling social identities (Lee 2008).

It is Norton's view $(1997,2000,2010)$ that the onus is on literacy and language teachers to investigate which identity positions offer their learners the best prospects for social engagement and interaction. In addition, the onus is also on teachers to identify, explore and remediate those pedagogical practices that marginalise learners through offering them limited identity positions.

This paper seeks to demonstrate that, perhaps not owing to, but rather in spite of, current policy around literacy teaching, innovative teachers are still exercising their agency, in often challenging circumstances, to offer learners varied opportunities to own the target language. They do 
this by presenting the language in meaningful and relevant contexts, which not only appeal to learners' existing diverse identities but also offer potentially more powerful identity positions for the future. This speaks to the concept of transformative pedagogy, a driving force for many committed literacy teachers in this complex, challenging but ultimately rewarding field.

\section{References}

Bakhtin, Mikhael (1986) Speech Genres and Other Late Essays, Translated by V. McGee, University of Texas Press, Austin, Texas.

Black, Stephen and Yasukawa, Keiko (2011) Adult literacy and Numeracy as Social Practices: What does this mean for pedagogy? Plenary presented at Australian Council for Adult Literacy (ACAL) conference 2011, Melbourne.

Bourdieu, Pierre (1977) Cultural Reproduction and Social Reproduction, in Karabel, Jerome and Halsey, A. H. (eds) Power and Ideology in Education, Oxford University Press, New York, pp 487-511.

Canagarajah, S (2004a) Subversive identities, Pedagogical Safe Houses and Critical Learning, in Norton, Bonny and Kelleen Toohey (eds) in Critical pedagogies and Language Learning, Cambridge University Press, Cambridge, pp116-137.

Cresswell, John (1998) Qualitative Inquiry and Research Design: Choosing among five approaches, Sage Publications, California.

Dornyei, Zoltan (1994) Motivation and Motivating in the Foreign Language Classroom, The Modern Language Fournal, Vol. 78, No. 3 (Autumn, 1994), pp 273-284.

Duff, Patricia (2002) The Discursive Co-construction of Knowledge, Identity, and Difference: An ethnography of communication in the high school mainstream,. Applied Linguistics, 23, pp 289-322.

Duff, Patricia (2008) Case Study Research in Applied Linguistics, Taylor and Francis, New York.

Duff, Patricia and Early, M. (1996) Problematics of Classroom Research Across Sociopolitical Contexts, in Gass, Susan and Jacquelyn Schachter (eds) Second,Language Classroom Research: Issues and opportunities pp 1-30 Lawrence Erlbaum, Hillsdale, New Jersey, pp 31-44.

Gass, Susan (1997) Input,Iinteraction, and the Second Language Learner, Lawrence Erlbaum and Associates, Mahwah, New Jersey.

Goldstein, Tara (2003) Teaching and Learning in a Multilingual School: Choices, risks and dilemmas, Lawrence Erlbaum, New Jersey.

Hall, Stuart (1997) Representation: Cultural representations and signifiying practices, Sage Publications, London.

Harklau, Linda (2000) From the 'Good kids' to the 'Worst': Representations of English language learners across educational settings, TESOL Quarterly, vol 34, no 1, pp 35-67. 
Hornberger, Nancy and Skilton Sylvester, Ellen (2000) Revisiting the Continua of Biliteracy: International and critical perspectives, Language and Education, vol 14, no 2, pp 96-122.

Hornberger, Nancy (ed) (2003) Continua of Biliteracy, Multilingual Matters, Glevedon, UK.

Jennings, Nancy E. (1996) Interpreting policy in real classrooms. Teachers College Press, New York, NY.

Lee, Ena (2008) The 'other(ing)' Costs of ESL: A Canadian case study. Journal of Asian Pacific Communication 18(1), pp 91-108.

Leung, Constant, Harris, Roxy and Rampton, Ben (2004) Living with Inelegance in Qualitative Research on Task-based Learning, in Norton, Bonny and Kelleen Toohey (eds) Critical Pedagogies and Language learning, pp 242-267.

Lightbown, Patsy and Spada, Nina (2006) How Languages are Learned, Oxford University Press, Oxford.

McKenna, Rosa and Fitzpatrick, Lynne (2005), Integrated Approaches to Teaching Adult Literacy in Australia: A snapshot of practice in community services, NCVER, Adelaide.

Miller, Jennifer (2011), Teachers' Work in Culturally and Linguistically Diverse Schools, Teachers and teaching: theory and practice, vol 17, no 4, , pp 451-466.

Norton, Bonny (ed.) (1997) Language and Identity. Special issue of TESOL Quarterly, vol 31, no 3, pp ??

Norton, Bonny (2000) Identity and Language Learning: Gender, ethnicity and educational change, Pearson Education, Harlow.

Norton, Bonny (2001) Non-participation, Imagined Communities and the Language Classroom, in M. Breen (ed) Learner Contributions to Language Learning: New directions in research, pp 159-171, Pearson Education Limited, London

Norton, Bonny (2010) Language and Identity, in Hornberger, Nancy and Sandra McKay (eds) Sociolinguistics and Language Education, Multilingual Matters, Bristol pp 349-369.

Norton, Bonny and Toohey, Kelleen (eds) (2004) Critical Pedagogies and Language Learning, Cambridge University Press, Cambridge.

Norton, Bonny and Toohey, Kelleen (2011) State of the Art article: Identity, language learning and social change, Language Teaching, vol 44, no 4, pp 412-446.

Norton Peirce, Bonny (1995) Social Identity, Investment, and Language Learning, TESOL Quarterly, vol 29, no1, pp 9-31.

Nunan, David (1992) Research Methods in Language Learning, Cambridge University Press, Cambridge.

Ollerhead, Sue (2010), Teacher Agency and Policy Response in the Adult ESL Literacy Classroom, TESOL Quarterly, vol 44, pp 606-618. 
Reeves, Jenelle (2009) Teacher Investment in Learner Identity, Teaching and Teacher Education, vol 25 pp 34-41.

Ritchie, William and Tej Bhatia (1996) (eds) Handbook of Second Language Acquisition, Academic Press, New York.

Schachter, Jacquelyn and Gass, Susan (1996) Second Language Classroom Research: Issues and opportunities, Lawrence Erlbaum and Associates, Mahwah, New Jersey.

Stake, Robert (1995) The Art of Case Study Research, SAGE publications, Thousand Oaks.

Stein, Pippa (2008) Multimodal Pedagogies in Diverse Classrooms: Representations, rights and resources, Routledge, London and New York.

Street, Brian (1984) Literacy in Theory and Practice, Cambridge, Cambridge University Press.

Street, Brian (2001) Literacy and Development: Ethnographic perspectives, Routledge, New York.

Talmy, S (2008) The Cultural Productions of the ESL Students at Tradewinds High: Contingency, multidirectionality, and identity in L2 socialization, Applied Linguistics vol 29, no 4, pp $619-644$.

Taylor, Charles (1992) Multiculturalism and 'the politics of recognition', Princeton University Press, Princeton, New Jersey.

Tett, Lyn, Hamilton, Mary and Hillier, Yvonne (2006) Adult Literacy, Numeracy and Language: Policy, practice and research, Open University Press, Milton Keynes.

Toohey (2000) Learning English at School: Identity, Social relations and classroom practice, Multilingual Matters, Clevedon.

Villenas, Sophia (2001) Latina Mothers and Small-town Racisms: Creating narratives of dignity and moral education in North Carolina, Anthropology and Education Quarterly, vol 32, pp 3-28.

Wallace, Ruth (2008) Reluctant Learners: Their identities and educational experiences, Occasional Paper, NCVER, Adelaide.

White, John Wesley (2011) Resistance to Classroom Participation: Minority students, academic discourse, cultural conflicts, and issues of representation in whole class discussions, Fournal of Language, Identity and Education, vol. 10, pp 250-265.

Wigglesworth, Gillian (2003) (ed) The Kaleidoscope of Adult Second Language Learning: Learner, teacher and researcher perspectives, Adult Migrant English Program (AMEP), Sydney.

Weedon, Christine (1997). Feminist Practice and Poststructuralist Theory (2nd edn). Blackwell, Oxford. 
'Passivity' or 'Potential'?

\section{Endnotes}

${ }^{1}$ The NRS was Australia's nationally recognised instrument for reporting outcomes of adult English language, literacy and numeracy programs. It was replaced by the Australian Core Skills Framework in 2009.

${ }^{2}$ Pseudonyms have been used to protect the identities of head teachers, teachers and learners, in compliance with ethical requirements. 
